\title{
Micrurus ibiboboca (Serpentes, Elapidae) is not a Guiana Shield Species
}

\author{
Ross D. MacCulloch and Amy Lathrop \\ Centre for Biodiversity and Conservation Biology, Royal Ontario Museum, 100 Queen's Park, Toronto, Ontario M5S \\ 2C6, Canada. Email: rossm@rom.on.ca.
}

Keywords: Serpentes, Elapidae, Micrurus ibiboboca, Micrurus lemniscatus, Guyana, Surinam, French Guiana, geographic distribution.

Coral snakes (Micrurus) are a diverse group of Neotropical squamates. Similarities in morphology and coloration can make identification difficult, especially in areas of species sympatry. Species with triad-type coloration, approximately $30 \%$ of all Micrurus species, are among the most difficult to identify. Micrurus ibiboboca Merrem, 1820 is an east Brazilian species with triad-type coloration. There are also reports of $M$. ibiboboca from the Guiana region, in Guyana, French Guiana and Surinam.

In a recent revision of the genus Micrurus, Roze (1996) stated that "isolated populations [of M. ibiboboca] are probably also found in Suriname and French Guiana", although the accompanying map of the species' distribution shows no records from north of the Amazon. Roze's distribution list by countries includes $M$. ibiboboca in the Surinam list, but not in the French Guiana list. In publications prior to 1996, Roze did not mention M. ibiboboca as occurring in French Guiana or Surinam (Roze 1967, 1983). Furthermore Roze (1996) suggested that the Guianan specimens of M. ibiboboca may really be $M$. isozonus.

Other authors have reported the occurrence of $M$. ibiboboca in the Guiana region. Abuys

Received 5 July 2004.

Accepted 23 November 2004.

Distributed December 2004.
(2003) stated that it occurs "in Suriname and also very probably in the other Guianas" based on two specimens "from the vicinity of Zanderij." Kok et al. (2003) stated that it had been "reported from northern Suriname", and "probably erroneously from northern French Guiana". Golay et al. (1993) stated the range of M. ibiboboca as "Surinam and Brazil." David and Ineich (1999) stated that the species occurs in French Guiana and Surinam, based on literature citations. Campbell and Lamar (1989) included records for $M$. ibiboboca from Surinam and French Guiana on the species' distribution map, but indicated that these were questionable. Campbell and Lamar (2004) suggested that the Guiana region specimens of $M$. ibiboboca are really $M$. lemniscatus diutius.

The sources of the reports of M. ibiboboca were traced and the specimens that they are based upon were examined. Identification was based on accepted criteria such as scale counts and banding pattern (Peters and Orejas-Miranda 1970, Chippaux 1986, Roze 1996, Starace 1998, Campbell and Lamar 2004). Below we examine each of the Guiana reports in detail.

Guyana - The record from Guyana was based on a specimen from southwestern Guyana at the Royal Ontario Museum (ROM 11702). This individual was determined to be a specimen of Micrurus lemniscatus; it has complete triads, discrete head bands, and 31 subcaudals; this last number is outside the 
range of Micrurus ibiboboca, but within the range of $M$. lemniscatus (Table 1).

The ROM specimen cannot be $M$. isozonus, which occurs in the same region (Kok et al. 2003), because of differences in the color pattern on the head. ROM 11702 has the pattern of sequential black-white-black-red head bands which is characteristic of M. lemniscatus; in $M$. isozonus the snout tip is never uniformly black (Roze 1996). The ROM specimen also exceeds the largest reported size for M. isozonus (981 $\mathrm{mm}$ vs $885 \mathrm{~mm}$ ).

According to the distribution maps in Roze (1996) and Campbell and Lamar (2004), ROM 11702 originated from within the range of $M$. lemniscatus diutius. The ROM specimen resembles $M$. $l$. diutius from French Guiana as described and illustrated in Starace (1998) more closely than it resembles the description of this subspecies in Roze (1966, 1996).

French Guiana - Roze (1996) and Campbell and Lamar (2004) cite Chippaux (1986) as listing M. ibiboboca from French Guiana. However, Chippaux (1986) says only that $M$. ibiboboca "...could possibly be collected there because it is present in neighbouring territory." Starace (1998) also treats the species as "possible presence" in French Guiana (along with four other species of Micrurus known from Surinam or Brazil). Other lists of snakes from French Guiana do not mention M. ibiboboca (Gasc and Rodrigues 1980, Rogé and Sauvenet 1987). We are therefore confident that the reports of $M$. ibiboboca from French Guiana are not based on specimen records, but only on speculation that the species could possibly occur there because it occurs in Brazil.

Surinam - The source of the reports of $M$. ibiboboca in Surinam is Abuys (1982) (cited in Roze 1996, David and Ineich 1999, Abuys 2003 and Campbell and Lamar 2004). Abuys (1982) based the claim on two specimens from northcentral Surinam. These two specimens, identified as M. ibiboboca, are in the collection of the Naturalis Museum in Leiden (RMNH 13780, RMNH 17277). Examination of these two specimens indicates that they are actually $M$. lemniscatus; they have sequential blackwhite-black-red head bands and the numbers of subcaudals fall outside the range of $M$. ibiboboca, but within the range of $M$. lemniscatus (Table 1).

Moonen et al. (1979) show a photograph of a snake purported to be M. ibiboboca. They state that the species "... was never found by the authors. The specimen in the picture was caught by others..." and "the provenance of the only specimen that we got to see is unknown, unfortunately." Abuys (1982) provides some corrections and additions to Moonen et al. (1979), and stated that the abovementioned quote in Moonen et al. (1979) should be replaced by "two specimens [of $M$. ibiboboca], one male and one female, [were] collected from the vicinity of Bosbivak Zanderij" (approximately $40 \mathrm{~km} \mathrm{~S}$ of Paramaribo). It is not explicitly stated whether the snake in the photograph is one of the two collected specimens.

Other text in Moonen et al. (1979) reads: "At first glance this species is easily confused with Micrurus lemniscatus. However, the yellow transverse bands are much wider here." It appears that color pattern, rather than scale counts, was used to identify the snake as $M$. ibiboboca. The photograph in Moonen et al. (1979) strongly resembles the ROM specimen, the RMNH specimens, and the photographs of M. l. diutius in Starace (1998). The white bands are broader in $M$. $l$. diutius from eastern and central Guiana than they are in individuals from the northwestern part of its range. In specimens from Trinidad and Venezuela the black bands are much broader than the white bands, whereas in specimens from Guyana, Surinam and French Guiana the white bands are approximately equal to the outer black bands. Specimens from French Guiana also have a greater number of ventrals and subcaudals than do Venezuelan specimens. This is evident in comparing the scale counts in Starace (1998) with those in Roze (1996) (summarised in Table 1). These 
Table 1 - Scale counts of Micrurus ibiboboca and M. lemniscatus diutius. Sample sizes are shown in parentheses.

\begin{tabular}{|c|c|c|c|c|c|c|}
\hline SPECIES & VENTRALS & SUBCAUDALS & $\begin{array}{c}\text { WIDTH OF } \\
\text { CENTRAL } \\
\text { BLACK BANDS }\end{array}$ & $\begin{array}{l}\text { WIDTH OF } \\
\text { OUTER BLACK } \\
\text { BANDS }\end{array}$ & $\begin{array}{l}\text { WIDTH OF } \\
\text { WHITE } \\
\text { BANDS }\end{array}$ & $\begin{array}{l}\text { WIDTH OF } \\
\text { RED } \\
\text { BANDS }\end{array}$ \\
\hline M. ibiboboca & o 206-247 (35) & $\sigma^{7} 20-28(35)$ & $4-8$ dorsals & $3-5$ dorsals & 2-4 dorsals & 8-13 dorsals \\
\hline (Roze 1996) & 우 216-254 (25) & 우 19-27 (25) & & & & \\
\hline M. l.diutius & o 212-225 (28) & $\sigma^{7} 31-38(28)$ & $7-12$ dorsals & half of central & $2+$ dorsals & 2-10 dorsals \\
\hline (Roze 1996) & 우 225-242 (21) & 우 31-37 (21) & & or more & & \\
\hline M. l. diutius & o 224-255 (2) & $\sigma^{\pi} 34-42(2)$ & 6-8 dorsals & 5-6 dorsals & 4-5 dorsals & $7-13$ dorsals \\
\hline (Starace 1998) & ㅇ $229-268$ (2) & 우 33-41 (2) & & & & \\
\hline ROM 11702 ㅇ & 228 & 31 & $6-8$ dorsals & 4-5 dorsals & 3-4 dorsals & 6-9 dorsals \\
\hline RMNH 13780 우 & 236 & 32 & 5-7 dorsals & 4-5 dorsals & 3-4 dorsals & 7-13 dorsals \\
\hline RMNH $17277 \sigma^{x}$ & 226 & 30 & 5-7 dorsals & 5-6 dorsals & 3-4 dorsals & 7-12 dorsals \\
\hline
\end{tabular}

differences are illustrated in the photographs of M. l. diutius from Venezuela (Roze 1966), Trinidad (Campbell and Lamar 2004) and French Guiana (Starace 1998).

Starace (1998) remarks on the considerable differences between M. l. lemniscatus and M. $l$. diutius in French Guiana. There is considerable variation both within and among the subspecies of M. lemniscatus, as evidenced by both meristics and photographs (Roze 1996, Campbell and Lamar 2004). Jorge da Silva and Sites (2001) found M. lemniscatus to be polyphyletic. Obviously, variation in $M$. lemniscatus requires further examination.

Micrurus ibiboboca and M. lemniscatus, especially $M$. $l$. diutius, resemble each other strongly, and confusion is understandable. The photographs of $M$. ibiboboca from Brazil in Campbell and Lamar (2004) strongly resemble those of M. l. diutius in Starace (1998). This confusion is reflected in the taxonomic history of the two species; they have been synonymised and separated twice (Amaral 1925, Schmidt 1936, Hoge 1952, Hoge and Romano 1973). Micrurus lemniscatus has also been confused with $M$. frontalis in northern Argentina (Jorge da
Silva and Silva 1996).

The inclusion of Micrurus ibiboboca in the Guiana region fauna was based on mistaken identification of specimens. The specimens from the Guiana region previously identified as Micrurus ibiboboca are in fact Micrurus lemniscatus diutius. There are no valid records of $M$. ibiboboca from the Guiana region. The range of $M$. ibiboboca is restricted to eastern Brazil, south of the Amazon.

\section{Acknowledgements}

We thank J.W. Arntzen (RMNH) for the loan of specimens. Pieter Michels and Andre Ngo kindly supplied some literature. Klaas Ruitenbeek provided translation. This is contribution 323 of the Centre for Biodiversity and Conservation Biology, ROM, and number 89 in the Smithsonian's Biological Diversity of the Guiana Shield Program publication series.

Specimens Examined: Micrurus lemniscatus diutius - GUYANA: Rupununi: Ruawau River (ROM 11702). SURINAM: Paramaribo: Zanderij vicinity (RMNH 13780, 17277). 


\section{References}

Abuys, A. 1982. Enige korrekties en aanvullende gegevens t.a.v. het boekje "Surinaamse slangen in kleur" van Joep Moonen e.a., 1979. Litteratura Serpentinum 2: 34-42.

Abuys, A. 2003. De slangen van Suriname en de andere Guyanas. Groningen. A. Abuys/Gopher Publishers. $592 \mathrm{pp}$.

Amaral, A. 1925. Da invalidez da espécie de colubrídeo elapíneo Micrurus ibiboboca (Merrem) e redescripção de M. lemniscatus (L.). Revista do Museu Paulista 15: 29-40.

Campbell, J. A. and W. W. Lamar. 1989. The Venomous Reptiles of Latin America. Ithaca. Cornell University Press. $425 \mathrm{pp}$.

Campbell, J. A. and W. W. Lamar. 2004. The Venomous Reptiles of the Western Hemisphere. Volumes 1 and 2. Ithaca. Cornell University Press. 774 pp.

Chippaux, J.-P. 1986. Les Serpents de la Guyane Francaise. Cayenne. ORSTOM Faune Tropical 27. 165 pp.

David, P. and I. Ineich. 1999. Les serpents venimeux du monde: systématique et répartition. Dumerilia 3: 1499.

Gasc, J.-P. and M. T. Rodrigues. 1980. Liste préliminaire des serpents de la Guyane française. Bulletin $d u$ Muséum National d'Histoire Naturelle, Paris 2: 559598.

Golay, P., H. M. Smith, D. G. Broadley, J. R. Dixon, C. McCarthy, J.-C. Rage, B. Schätti and M. Toriba. 1993. Endoglyphs and Other Major Venomous Snakes of the World - a checklist. Geneva. Azemiops S.A. 478 pp.

Hoge, A. R. 1952. Notas Erpetologicas. $1^{\text {a }}$ contribuição ao conhecimento dos ofídios do Brasil central. Memórias do Instituto Butantan 24: 179-214.

Hoge, A.R. and W.D.L. Romano. 1973. Sinopse das serpentes peçonhentas do Brasil. Serpentes, Elapidae, Viperidae. Memórias do Instituto Butantan 36: 109_ 207.
Jorge da Silva, N. and D. J. Silva. 1996. Geographic distribution: Micrurus lemniscatus. Herpetological Review 27: 34.

Jorge da Silva, N. and J. W. Sites. 2001. Phylogeny of South American triad coral snakes (Elapidae: Micrurus) based on molecular characters. Herpetologica 57: $1-22$.

Kok, P. J. R., J. A. Roze, G. L. Lenglet, H. Sambhu, and D. Arjoon. 2003. Micrurus isozonus (Cope, 1860) (Serpentes, Elapidae): an addition to the herpetofauna of Guyana, with comments on other species of coral snakes from Guyana. Bulletin de l'Institut Royal des Sciences Naturelles de Belgique 73: 73-79.

Moonen, J., W. Eriks and K. van Deursen. 1979. Surinaamse Slangen in Kleur. Paramaribo. C. Kersten and Co. 119 pp.

Peters, J. W. and B. Orejas-Miranda. 1970. Catalogue of the Neotropical Squamata: Part 1. Snakes. United States National Museum Bulletin 297: 1-347.

Rogé, J.-P. and J. Sauvenet. 1987. Les Serpents. Cayenne. Saga Éditions. 32 pp.

Roze, J. A. 1966. La Taxonomia y Zoogeografia de los Ofidios de Venezuela. Caracas. Universidad Central de Venezuela. $362 \mathrm{pp}$.

Roze, J. A. 1967. A checklist of the New World venomous coral snakes (Elapidae) with descriptions of new forms. American Museum Novitates 2287: 1-60.

Roze, J. A. 1983. New World coral snakes (Elapidae): a taxonomic and biological summary. Memórias do Instituto Butantan 46: 305-338.

Roze, J. A. 1996. Coral Snakes of the Americas - biology, identification, and venoms. Malabar. Krieger Publishing. 328 pp.

Schmidt, K. P. 1936. Preliminary account of coral snakes of South America. Zoological Series, Field Museum of Natural History 20: 189-203.

Starace, F. 1998. Guide des Serpents et Amphisbènes de Guyane. Paris. Ibis Rouge Editions. 449 pp. 